\title{
Comparison of the impact factors of subscription access and open access orthopedics and sports medicine journals in the SCImago database
}

\author{
Abonelik erişimli ve açık erişimli ortopedi ve spor hekimliği dergilerinin SClmago veri tabanındaki \\ etki faktörlerinin karşılaştırıması
}

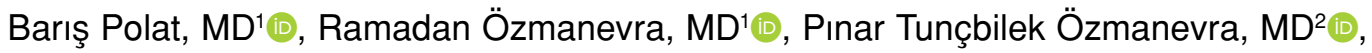 \\ Kadir Çağdaş Kazıkdaş, $M^{3}{ }^{3}$ \\ 1Department of Orthopedics and Traumatology, University of Kyrenia, Faculty of Medicine, Kyrenia, Cyprus \\ ${ }^{2}$ Department of Otorhinolaryngology, University of Kyrenia, Faculty of Medicine, Kyrenia, Cyprus \\ ${ }^{3}$ Department of Otorhinolaryngology, Near East University, Faculty of Medicine, Nicosia, Cyprus
}

\begin{abstract}
Objectives: This study aims to compare the annual impact factors (IFs) for the period 1999-2017 and the tri-annual IFs in 2011, 2014 and 2017 of the subscription access (SA) and open access (OA) journals published in the field of orthopedics, traumatology and sports medicine according to the SCImago Journal Rank (SJR).

Material and methods: All data for this study were obtained from the SCImago Journal \& Country Rank database. We compared the change in the mean annual IFs of 197 SA journals with 52 OA journals in the field of orthopedics and sports medicine for the period between 1999 and 2017. In addition, we determined and compared the changes in the mean tri-annual IFs of these journals in 2011, 2014 and 2017. The mean publication fee values of the OA journals as well as the correlation between the three-year IFs of the year 2017 and the publication fee values were evaluated.
\end{abstract}

Results: From 1999 to 2017, the mean IF of SA journals increased 0.47 -fold to 0.69 , while the mean IF of the OA journals increased 0.85 -fold to 0.63 . Significant positive correlation was observed between the tri-annual IF and publication fee of OA journals in $2017(\mathrm{r}=0.458, \mathrm{p}=0.001)$.

Conclusion: We can predict that the mean IFs of OA journals in the field of orthopedics and sports medicine will reach the mean IFs of SA journals after several years. Choosing OA journals becomes advantageous when the desire for a higher number of citations is the most important factor.

Keywords: Impact factor, open access, SCImago Journal Rank, subscription access.

\section{ÖZ}

Amaç: $\mathrm{Bu}$ çalışmada ortopedi, travmatoloji ve spor hekimliği alanında yayınlanan abonelik erişimli (ABE) ve açık erişimli (AÇE) dergilerin SCImago Dergi Sıralaması (SDS)'na göre 1999-2017 dönemi için yıllık etki faktörleri (EF'leri) ile 2011, 2014 ve 2017'deki üç yıllık EF'leri karşılaştırıldı.

Gereç ve yöntemler: $\mathrm{Bu}$ çalışma için tüm veriler SCImago Dergi \& Ülke Siralaması veri tabanından elde edildi. Ortopedi ve spor hekimliği alanında 1999 ve 2017 arasındaki dönem için 197 ABE dergi ile 52 AÇE derginin ortalama yıllık EF'lerindeki değişim karşılaştırıldı. Ayrıca, bu dergilerin 2011, 2014 ve 2017'de ortalama üç yıllık EF'lerindeki değişiklikler belirlendi ve karşılaştırıldı. Açık erişimli dergilerin ortalama yayın ücreti değerleri ile beraber 2017 yılının üç yıllık EF'leri ve yayın ücreti değerleri arasındaki ilişki değerlendirildi.

Bulgular: Abonelik erişimli dergilerin ortalama EF'si 1999'dan 2017'ye 0.47 kat artarak 0.69'a, AÇE dergilerin ortalama EF'si ise 0.85 kat artarak 0.63'e ulaştı. Açık erişimli dergilerin 2017 yılında üç yıllık EF ve yayın ücreti arasında anlamlı pozitif ilişki gözlemlendi $(r=0.458, p=0.001)$.

Sonuç: Ortopedi ve spor hekimliği alanındaki AÇE dergilerin ortalama EF'lerinin birkaç yıl sonra ABE dergilerin ortalama EF'lerine ulaşacağı öngörülebilir. Daha yüksek sayıda atıf isteği en önemli faktör olduğunda AÇE dergilerin seçilmesi avantajlı olmaktadır.

Anahtar sözcükler: Etki faktörü, açık erişimli, SCImago Dergi Sıralaması, abonelik erişimli.

Received: January 08, 2019 Accepted: March 15, 2019 Published online: May 27, 2019

Correspondence: Barış Polat, MD. Dr. Suat Günsel Girne Üniversitesi Hastanesi, Ortopedi ve Travmatoloji Anabilim Dalı, 99320 Girne, KKTC. Tel: +90 392 - 6502630 e-mail: drbpolat@hotmail.com 
The most effective and easy way of accessing knowledge is the article sources published in scholarly journals. Access to articles in journals, which are very important for following the current literature, can be limited because they are usually subscription based. Open access (OA) enables information to be accessed easily with only one mouse click without requiring membership, registration or payment. Therefore, OA has become an increasingly common policy in many scholarly journals. ${ }^{[1]}$ However, there are still ongoing discussions based on doubts and concerns regarding the lack of quality peer review and the presence of predatory journals. ${ }^{[2]}$ The reason behind these doubts is the potential impact of the article processing charge (APC) requested from authors rather than readers by OA journals.

Impact factor (IF) is the most important and commonly used parameter for determining the quality of a journal. The IF of a journal was first introduced in 1955 by the Institute for Scientific Information, which was founded by Eugene Garfield. ${ }^{[3]}$ Impact factor is calculated based on the number of citations of articles published in the journal and is a reflection of the quality of the journal. ${ }^{[4]}$ Alternatively, a group of researchers developed an indicator called the SCImago Journal Rank (SJR) from Spanish universities for assessing the quality of scientific journals. ${ }^{[5]}$ Studies comparing the impact factors of $\mathrm{OA}$ and subscription access (SA) journals have been widely conducted in many medical fields. ${ }^{[6,7]}$ There are a limited number of studies comparing the IFs of OA and SA in the field of orthopedics and sports medicine journals aimed at addressing these concerns in OA publishing ${ }^{[6]}$ Therefore, in this study, we aimed to compare the annual IFs for the period 1999-2017 and the tri-annual IFs in 2011, 2014 and 2017 of the SA and OA journals published in the field of orthopedics, traumatology and sports medicine according to the SJR. ${ }^{[8]}$

\section{MATERIALS AND METHODS}

This study was conducted at University of Kyrenia Dr. Suat Günsel Hospital between September 2018 and December 2018. All data for this study were obtained from the SCImago Journal \& Country Rank database. The data from the SCImago database were easily obtained through the website. We compared the change in the mean annual IFs of 197 SA journals with $52 \mathrm{OA}$ journals in the field of orthopedics and sports medicine for the period between 1999 and 2017. Additionally, we determined and compared the changes in the tri-annual IFs of these groups of journals in 2011, 2014 and 2017. The mean publication fee values of the OA journals, the correlation between the three-year IFs of 2017 and the publication fee values were all evaluated. The total number of OA and SA journals, the number of citable documents published by the journal in the last three years and the number of last three years' total citations in 1999 and 2017 were also compared to determine the trends in journal publishing policy in the field of orthopedics and sports medicine.

\section{Statistical analysis}

Mean, standard deviation, median lowest, highest, frequency and ratio values were used in the descriptive statistics of the data. The distribution of the variables was measured with the Kolmogorov-Smirnov and chi-square test. The Mann-Whitney U test was used to analyze the quantitative independent data. The Wilcoxon test was used for the analysis of dependent

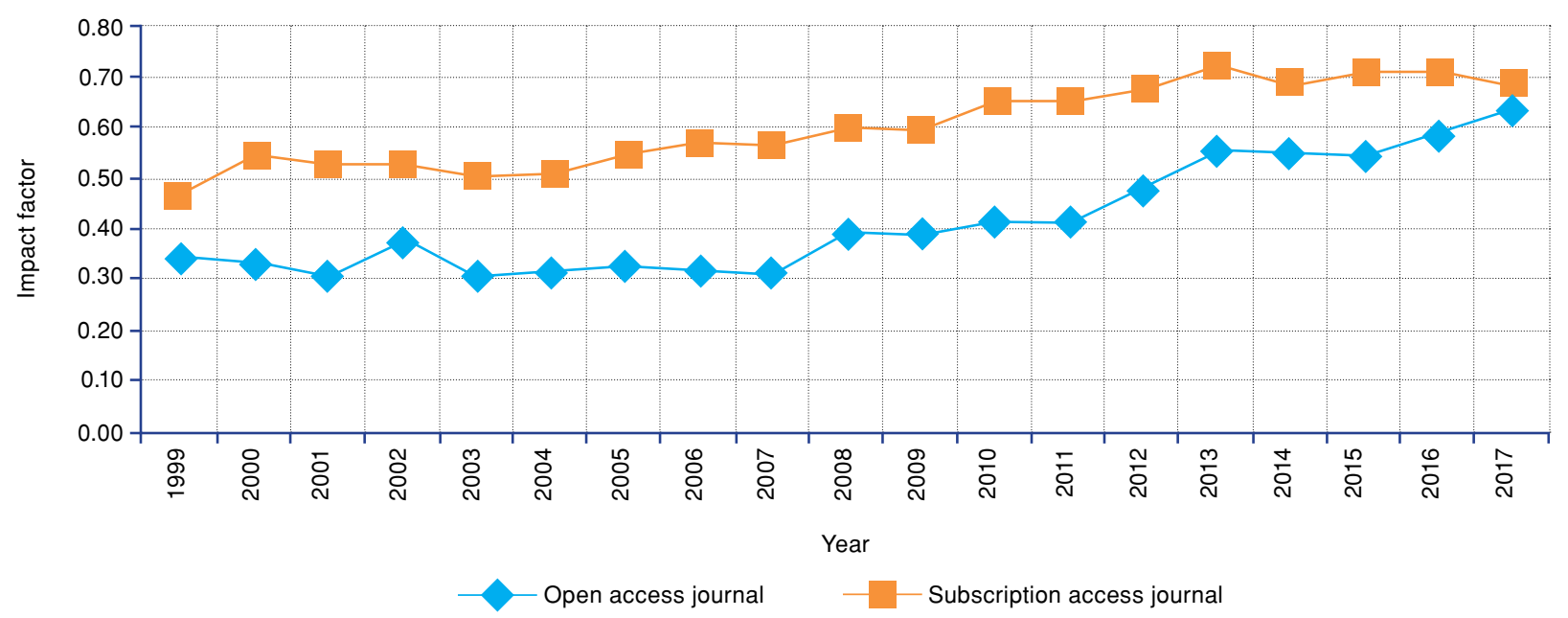

Figure 1. Distribution of mean annual impact factors over years by subscription and open access journals. 
TABLE I

Distribution of mean tri-annual impact factors in 2011, 2014 and 2017 by subscription and open access journals

\begin{tabular}{|c|c|c|c|c|c|}
\hline & \multicolumn{2}{|c|}{ Open access journals } & \multicolumn{2}{|c|}{ Subscription access journals } & \multirow[b]{2}{*}{$p$} \\
\hline & Mean $\pm S D$ & Median & Mean \pm SD & Median & \\
\hline 2011-3 years & $0.9 \pm 0.9$ & 0.62 & $1.4 \pm 1.3$ & 1.06 & $0.103^{*}$ \\
\hline Difference with $2011 p$ & \multicolumn{2}{|c|}{$0.000 \dagger$} & \multicolumn{2}{|c|}{$0.000 \dagger$} & \\
\hline 2014-3 years & $1.2 \pm 1.0$ & 1.07 & $1.6 \pm 1.5$ & 1.14 & $0.380^{*}$ \\
\hline Difference with $2014 p$ & \multicolumn{2}{|c|}{$0.000 \dagger$} & \multicolumn{2}{|c|}{$0.005 \dagger$} & \\
\hline 2017-3 years & $1.6 \pm 1.7$ & 1.38 & $1.5 \pm 1.4$ & 1.29 & $0.551^{*}$ \\
\hline Difference with $2014 p$ & \multicolumn{2}{|c|}{$0.036 \dagger$} & \multicolumn{2}{|c|}{$0.157 \dagger$} & \\
\hline
\end{tabular}

SD: Standard deviation; * Mann-Whitney $U$ test; $†$ Wilcoxon test.

quantitative data, while the Spearman rank correlation test was used for analyzing the correlation.

\section{RESULTS}

In 1999, the mean IF of SA journals was 0.47, while the mean IF for OA journals was 0.34. In 2017 compared to 1999, the mean IF of SA journals increased by 0.47 -fold to 0.69 , while the mean IF of OA journals increased 0.85-fold to 0.63 (Figure 1).

In the SA group, the mean tri-annual IF increased significantly $(\mathrm{p}<0.05)$ in 2014 compared to 2011. The mean tri-annual IF did not show a significant $(p>0.05)$ change in 2017 compared to 2014. In the OA group, the mean tri-annual IF increased significantly $(\mathrm{p}<0.05)$ in 2014 compared to 2011. The mean tri-annual IF increased significantly $(\mathrm{p}<0.05)$ in 2017 compared to 2014 (Table I).

From 1999 to 2017, OA journals showed a statistically significant increase compared to the SA journals in terms of total number of journals, the number of citable documents published by the journal in the last three years and the number of last three-years' total citations $(\mathrm{p}<0.0001)$ (Table II). The mean publication fee value of the 52 OA journals was calculated as $\$ 937$ (range, \$0-3125). Furthermore, 21 of these journals did not charge any publication fee, while others demanded a specific fee for publication. Significant positive correlation was observed between the triannual IF and publication fee of OA journals in $2017(\mathrm{r}=0.458, \mathrm{p}=0.001)$ (Figure 2).

\section{DISCUSSION}

The most important finding of this study is that the mean IF of OA journals in orthopedics and sports medicine in 2017 is almost identical to that of SA journals. This shows that although OA journals have to claim an APC, this does not adversely affect the quality of the articles in the journal. Due to the

TABLE II

Proportions of open and subscription access journals in total number of journals, last three years' citable documents and last three years' total citations in 1999 and 2017

\begin{tabular}{|c|c|c|c|c|c|c|c|}
\hline & \multicolumn{2}{|c|}{ Open access journals } & \multicolumn{2}{|c|}{ Subscription access journals } & \multicolumn{2}{|c|}{ Total } & \multirow[b]{2}{*}{$p$} \\
\hline & $\mathrm{n}$ & $\%$ & $\mathrm{n}$ & $\%$ & $\mathrm{n}$ & $\%$ & \\
\hline Journals & & & & & & & $<0.0001$ \\
\hline 1999 & 7 & 6 & 109 & 94 & 116 & 100 & \\
\hline 2017 & 52 & 20.9 & 197 & 79.1 & 249 & 100 & \\
\hline Citable documents (3 years) & & & & & & & $<0.00001$ \\
\hline 1999 & 1,419 & 5.2 & 25,756 & 94.8 & 2,7175 & 100 & \\
\hline 2017 & 10,443 & 15 & 59,199 & 85 & 69,642 & 100 & \\
\hline Total citations (3 years) & & & & & & & $<0.0001^{*}$ \\
\hline 1999 & 552 & 2 & 27,465 & 98 & 2,8017 & 100 & \\
\hline 2017 & 18,408 & 12.1 & 134,226 & 87.9 & 152,634 & 100 & \\
\hline
\end{tabular}

${ }^{*}$ Chi-square test with Yates' correction for continuity. 


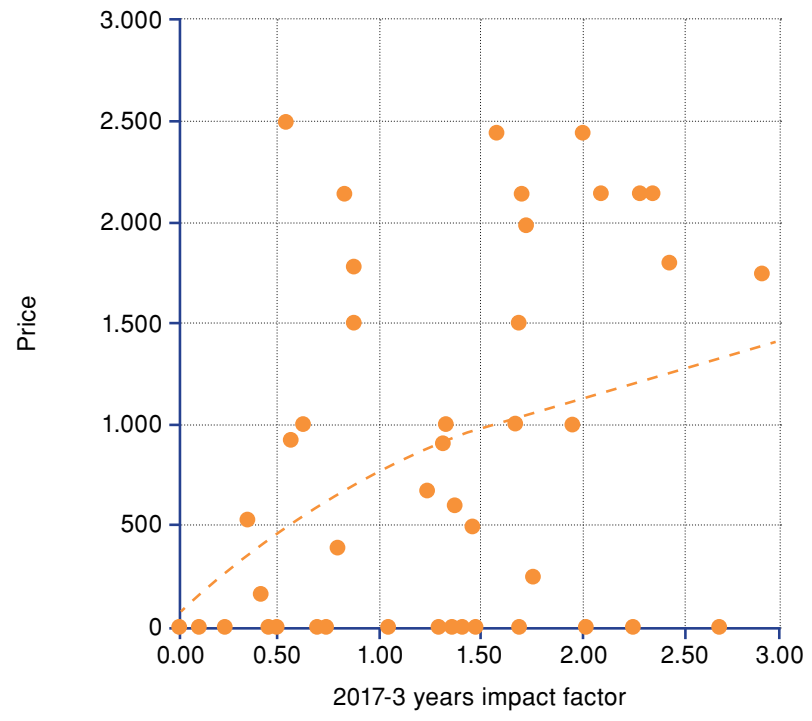

Figure 2. Positive correlation between publication fee and three-year impact factor for open access journals in 2017.

easy access to knowledge in OA journals, the articles here have increased the IFs of the journals that are published with more citations. ${ }^{[9]}$

The SJR indicator is calculated in a sophisticated manner by evaluating different data according to journal IF. Many different points are considered in the calculation of the journal IF and SJR indicator. The most significant factor in determining the IF is the sources of citations. SJR uses Scopus, a database that contains articles from many notable countries and languages. ${ }^{[10]}$ However, journal IF uses the Web of Science (WoS) database, underestimating nonEnglish journals, which comprise $15 \%$ of all scientific journals. ${ }^{[1]}$ The SJR indicator not only considers the citation number but also the quality of the journal that has been cited and the popularity of the research paper in Google search. Furthermore, the SJR indicator calculates the IFs of the journals without taking into account the self-citation of the journals. This situation prevents the editors from prioritizing review articles and self-citation articles and reducing the total number of articles published in the journal to increase the IFs of their journals. ${ }^{[12]}$ For these reasons, this study used the SJR indicator values instead of journal IF when comparing the IFs of journals.

The fact that OA journals had to demand APCs from the authors led to a steady increase in the number of predatory journals. ${ }^{[2]}$ Predatory journals threaten high-quality medical research. The authors have an important role in recognizing and avoiding these journals. ${ }^{[13]}$ The disadvantage of choosing OA journals includes doubts and concerns regarding the lack of quality peer review and the presence of predatory journals. The peer review quality may be queried because the income of OA journals that are not funded by any organization is proportional to the number of articles published. In order to eliminate these doubts and concerns related to OA journals, the authors should be very careful when choosing the journal. The visibility, prestige, IF and indexing by international services seem to constitute a quick and effective list of criteria for eliminating these concerns. ${ }^{[13]}$

Open access publishing has different modalities called hybrid, green and gold. Hybrid OA means that after the APC is paid to the SA journals by the author, the article will be free for public access on the website. In green OA, researchers can reach the articles via the repositories of the institutions. Finally, in gold OA, researchers have unlimited access to articles via the journals' website. ${ }^{[14]}$ Gold OA publishing has become an attractive option for both researchers and journals. In our study, OA journals covered $6 \%$ of all journals in 1999, while this ratio increased to $20.9 \%$ in 2017 . The increase in both the ratio of OA journals and the mean IFs compared to the SA journals are indications that OA publishing has drawn attention to this shift in publishing trends in recent years. More importantly, research funders in more than 10 European countries have announced 'Plan $S^{\prime}$ to make all scientific works free to read in the next two years. ${ }^{[15]}$ The publication strategies and models of articles published in refereed scientific journals have experienced a revolution in the last 30 years and it appears that this situation will continue.

While some of the OA journals are funded by various organizations, many of them demand APC. Thus, in the field of orthopedics and sports medicine in 2017, a total of 21 OA journals were funded by various organizations, while $31 \mathrm{OA}$ journals demanded APCs. This may lead to the expectation that APC-demanding OA journals will have less quality publications. In our study, significant positive correlation was observed between the tri-annual IF and publication fee of OA journals in $2017(\mathrm{r}=0.458$, $\mathrm{p}=0.001$ ). This analysis refutes this belief. With regard to this topic, in a recent study involving OA surgical journals, there was a slight positive correlation found between APC and their IF. ${ }^{[16]}$

In a comprehensive study comparing the 1,327 OA journals and 11,124 SA journals which are indexed in the WoS and/or Scopus database, OA journals were shown to have similar IFs compared to SA journals. ${ }^{[7]}$ Although the overall level of IFs of SA journals in 
the field of otorhinolaryngology was generally high, it was obvious that the level of increase of the IFs of OA journals was significantly higher by using regression models. ${ }^{[17]}$

In 2017 , only $13.5 \%$ of the OA journals indexed in the SCImago database in the field of orthopedics and sports medicine were also indexed in 1999, while $55.3 \%$ of SA journals were also indexed in 1999. Although the majority of the OA journals are relatively new publications, reaching almost the same mean IF as the well-established SA journals can be an indication of the achievement of OA publishing.

This study has some limitations. The number of OA journals is lower than SA journals. However, the establishment date of journals are different.

In conclusion, we can predict that the mean IFs of OA journals in the field of orthopedics and sports medicine will reach the mean IF of SA journals after several years. The trend of OA publishing in the field of orthopedics and sports medicine continues to increase. Authors consider various factors such as the journal's prestige, cost of publication, IF or SJR indicator value, peer review process and publication speed before submitting their articles. Choosing OA journals becomes advantageous when the desire for a higher number of citations is the most important factor.

\section{Declaration of conflicting interests}

The authors declared no conflicts of interest with respect to the authorship and/or publication of this article.

\section{Funding}

The authors received no financial support for the research and/or authorship of this article.

\section{REFERENCES}

1. Van Noorden R. Open access: The true cost of science publishing. Nature 2013;495:426-9.

2. Rupp M, Anastasopoulou L, Wintermeyer E, Malhaan D, El Khassawna T, Heiss C. Predatory journals: a major threat in orthopaedic research. Int Orthop 2019;43:509-17.
3. Sabharwal S, Patel N, Johal K. Open access publishing: a study of current practices in orthopaedic research. Int Orthop 2014;38:1297-302.

4. Garfield E. The history and meaning of the journal impact factor. JAMA 2006;295:90-3.

5. Garfield E. Citation analysis as a tool in journal evaluation. Science 1972;178:471-9.

6. Pastorino R, Milovanovic S, Stojanovic J, Efremov L, Amore R, Boccia S. Quality assessment of studies published in open access and subscription journals: results of a systematic evaluation. PLoS One 2016;11:e0154217.

7. Atayero AA, Popoola SI, Egeonu J, Oludayo O. Citation analytics: Data exploration and comparative analyses of CiteScores of Open Access and Subscription-Based publications indexed in Scopus (2014-2016). Data Brief 2018;19:198-213.

8. Atik OŞ. Which articles do we prefer to publish? Eklem Hastalik Cerrahisi 2018;29:1.

9. Li Y, Wu C, Yan E, Li K. Will open access increase journal CiteScores? An empirical investigation over multiple disciplines. PLoS One 2018;13:e0201885.

10. SCImago 2007. SJR-SCImago Journal \& Country Rank. Available from: http://www.scimagojr.com [Access: January 20, 2008]

11. Falagas ME, Pitsouni EI, Malietzis GA, Pappas G. Comparison of PubMed, Scopus, Web of Science, and Google Scholar: strengths and weaknesses. FASEB J 2008;22:338-42.

12. De Moya-Anegon F, Chinchilla-Rodriguez Z, VargasQuesada B, Corera-Alvarez E, Munoz-Fernandez FJ, Gonzalez-Molina, et al. Coverage analysis of Scopus: a journal metric approach. Scientometrics 2007;73:53-78.

13. Baker EF, Iserson KV, Aswegan AL, Larkin GL, Derse AR, Kraus CK. Open Access Medical Journals: Promise, Perils, and Pitfalls. Acad Med 2019;94:634-9.

14. Piwowar H, Priem J, Larivière V, Alperin JP, Matthias L, Norlander B, et al. The state of OA: a large-scale analysis of the prevalence and impact of Open Access articles. PeerJ 2018;6:e4375.

15. Else H. Radical open-access plan could spell end to journal subscriptions. Nature 2018;561:17-18.

16. Yuen J, Muquit S, Whitfield PC. Correlation between cost of publication and journal impact. comprehensive crosssectional study of exclusively open-access surgical journals. J Surg Educ 2019;76:107-19.

17. Kazikdas KC, Tanik M, Ural A. Changing trends in otorhinolaryngology publishing. Acta Otorhinolaryngol Ital 2019. [Epub ahead of print] 